\title{
PERBEDAAN PENDAPAT ULAMA TENTANG URGENSI FILSAFAT DALAM ISLAM
}

\author{
M.Basir Syam
}

\begin{abstract}
Abstrak
Di kalangan para ulama sejak awal telah terjadi perbedaan pendapat dalam menggunakan akal dalam persoalan keagamaan, ada kelompok ahlu al naqli dan ahlu al ra'yi. Pada masa awal perkembangan Islam umumnya didominasi kaum ahlu al naqli.Setelah daerah kekuasaan Islam meluas ulama ahlu al ra'yi yang dimotori oleh kaum Mu'tazilah tanpil menggunakan argumentasi rasional untuk meyakinkan kebenaran Islam terhadap kalangan para penentang. Kaum Asy'ariyah dan Maturidiyah yang mengeritik sikap liberal Mu'tazilah walaupun membatasi diri,tetapi mereka menggunakan argumentasi rasional dalam mempertahankan pandangan shalafusshalih. Al-Ghazali sebagai seorang Asy'ariyah, malahan ketika mengeritik penyimpangan para filosof, justru menggunakan argument filosofis pula. Dalam kitabnya "Tahafutul Falasifah" kritikannya tidak menggunakan dalil naqli. Dengan kitab itu pula yang mempopulerkan dirinya sebagai seorang filosof. Ulama yang datang kemudian seperti Ibnu al-Shalah, Ibnu Taimiyah, Ibnul Qayyim dan Muhamad Ibn al-Wahhab adalah merupakan penentang filsafat.
\end{abstract}

\section{Keywords: \\ Ulama dan Filsafat.}

Pada tulisan ini penulis bermaksud menguraikan sikap ulama dalam menghadapi pemikiran filsafat. Hal ini dianggap perlu mengingat pendapat Tennemann mengenai adanya golongan Ahlus-Sunnah yang menjadi faktor penghalang bagi orang-orang Arab sehingga tidak mampu berfilsafat. Juga mengenai stagnasi filsafat Islam yang selalu dikaitkan dengan penampilan al-Gazali.

Dalam sejarah perkembangan pemikiran Islam memang benar adanya dua sikap yang bertentangan di kalangan ulama. Sebahagian mereka dikenal sebagai "ahlu n-naql" sementara yang lainnya dikenal sebagai "ahlu r-rayi. H.A.R. Gibb menyebut kedua golongan itu sebagai golongan "ortodoks" dan "rasionalis," yang dimaksudkan Gibb dengan golongan ortodoks termasuk kaum Asylariyah yang berhadapan dengan kaum Mu'tazilah.

Sejak awal perkembangan Islam para ulama telah menggunakan akal pikiran dalam membicarakan persoalan-persoalan keagamaan. Akan tetapi hal ini masih terbatas sekali terutama pada persoalan-persoalan syariat Islam, mengingat situasi dan 
kondisi belum mengizinkan untuk hal itu. Ketika itu juga telah ada berlaku di kalangan ulama prinsip berpegang teguh pada Nash yang ada, tanpa mengikutsertakan akal pikiran, khususnya dalam menghadapi persoalan-persoalan aqidah. Lalu setelah meluasnya daerah-daerah kekuasaan Islam, seperti yang telah disebutkan, di antara ulama mulai menggunakan akal secara lugas dalam rangka pembelaan terhadap serangan pemeluk agama-agama lain.

Kalau kaum Mu'tazilah terkenal sebagai peletak batu pertama bagi lahirnya filsafat Islam di kemudian hari, maka oleh sebahagian penulis sejarah menganggap Asy'ari dan pengikut-pengikutnya sebagai anti akal atau filsafat, tetapi hendaknya dimaklumi bahwa kaum Ahlus-Sunnah ini juga tetap menggunakan akal walaupun terbatas, sepanjang tidak menyalahi ketentuan-ketentuan nash-nash agama. Karena itu berbeda dengan kelompok yang panatik terhadap makna lahiriah nash al-Qur'an dan alHadits dan pantang sekali menggunakan akal. Kelompok terakhir ini terkenal sebagai "Ahlu dz-Dzahir" atau golongan tekstualis. ${ }^{1}$ Mungkin inilah yang dimaksudkan oleh Tennemann.

Baik Mu'tazilah maupun Asy'ari dan pengikut-pengikutnya memandang perlu menggunakan akal, hanya saja otoritasnya berbeda. Kaum Mu'tazilah berusaha menyesuaikan makna nash dengan akal, sedangkan kelompok Asy'ari hanya menggunakan akal untuk memberikan argumentasi tentang kebenaran yang terkandung pada nash-nash tersebut. Dengan demikian sikap Asy'ari dalam menghadapi golongan Mu'tazilah, walaupun oleh beberapa penulis menganggapnya sebagai penolakan secara tidak langsung terhadap filsafat, namun tidak benar sepenuhnya bila dikaitkan dengan pendapat Tennemann tersebut.

Al-Gazali sendiri yang terkenal sebagai tokoh ulama yang telah mengeritik pemikiran para filosof secara terangterangan, tidak serta-merta menggunakan nash-nash agama, melainkan menggunakan senjata akal, tidak heran kalau ia digolongkan juga sebagai filosof Islam, apalagi melihat beberapa karyanya yang menunjukkan keahliannya dalam bidang itu.

Kalau diperhatikan secara seksama karya-karya alGazali mengenai kritikannya terhadap pemikiran para filosof, bukannya mengingkari filsafat, akan tetapi pada

\footnotetext{
${ }^{1}$ Syekh Muhammad Abduh, Risalatu t-Tauhid (cetakan Qairo: Maktabah wa Muthba'ah Muhammad Ali Shabih wa Auladih, 1965), h. 12 dan 13.
} 
hakekatnya ia ingin meluruskan pemikiran itu ke arah yang lebih baik, lebih sesuai dengan prinsip-prinsip Islam. Al-Gazali tidak mengkafirkan para filosof karena filsafat itu sendiri, melainkan karena pemikiran-pemikirannya yang tertentu. Juga perlu diperhatikan bahwa ia bukan saja mengeritik para filosof, akan tetapi menyeluruh pada semua golongan yang ada pada masanya, termasuk kalangan sufi yang kemudian menjadi temannya dalam berkhalwat dan bertafakkur.

Sebenarnya sikap yang menolak filsafat dalam dunia pikir Islam datang sesudah masa al-Gazali, terutama setelah wafatnya Ibnu Rusyd, yang ketika itu tidak ada lagi orang-orang yang mampu berpikir kreatif seperti dia. Atau karena filsafat telah jauh berpisah dengan ilmu pengetahuan, seperti pendapat al-Ahwani. Apalagi ketika itu sikap latah telah menyelimuti kemerdekaan berpikir di kalangan umat. Lalu timbullah sikap a priori yang menolak secara total pemikiran filosofis, mencemohkan logika dan menganggapnya sebagai kegiatan kekafiran.

Ibnu Ash-Shalah (wafat $643 \mathrm{H}$ ) ketika diminta pendapatnya mengenai filsafat dan ilmu mantik antara lain ia berkata,

Filsafat adalah pokok kebodohan dan penyelewengan, bahkan kebingungan dan kesesatan. Siapa yang berfilsafat maka butalah hatinya dari kebaikan-kebaikan syari'ah yang suci yang dikuatkan dengan dalil-dalil yang lahir dan bukti-bukti yang jelas. Barang siapa yang mempelajarinya, maka ia berteman kehinaan, tertutup dari kebenaran dan terbujuk oleh syetan. Apakah ada ilmu lain yang lebih hina daripada ilmu yang membutakan dari orang yang memilikinya dan menggelapkan hatinya dari sinar kenabian Nabi kita. ${ }^{2}$

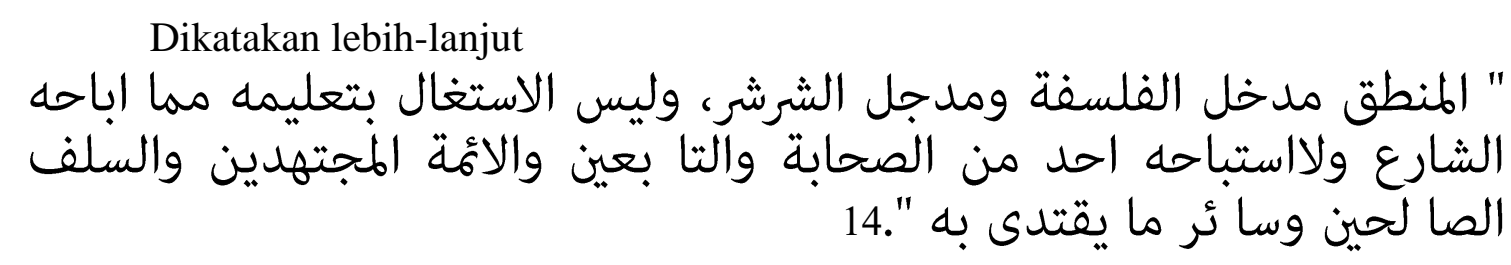

Artinya:

Ilmu mantik adalah jalan menuju filsafat, sedang jalan kepada keburukan tentu keburukan pula. ${ }^{3}$ Mempelajari mantik dan mengajarkannya tidak termasuk

${ }^{2}$ A. Hanafi, op. cit., h. 33.

${ }^{3}$ Ali Samiy an-Nasysyar, Manahiju 1-Bahts 'Inda Mufakkiri 1-Islam (cetakan I, Qairo: Daru 1-

Fikri I- Arabiy, 1947)t h. 142. 
perkara yang diperbolehkan oleh syara. Juga tidak direstui seorangpun dari kalangan sahabat, tabiin, imam-imam mujtahidin, salafu sh-shalih dan semua yang mengikutinya.

Ibnu Taimiyah (wafat $728 \mathrm{H}$ ), seorang tokoh aliran Salaf yang telah memerangi fungsi akal dalam membicarakan persoalan-persoalan keagamaan, termasuk filsafat Islam yang dimaksudkan sebagai usaha singkretisasi antara filsafat Yunani dengan ajaran Islam. Bagi Ibnu Taimiyah, segala unsur pemikiran asing tidak pada tempatnya dicampuradukkan dengan ajaran Islam. Kitabnya yang berjudul "Muwafaqatu Shahihi 1-Manquli sh-Sharihi 1-Ma'qul" dikhususkan untuk menolak segala bentuk pemikiran asing yang masuk ke dalam Islam, terutama filsafat. Ia menegaskan hasil pemikiran kaum muslimin yang berupa filsafat pada hakekatnya tidak lain dari persangkaanpersangkaan atau hayalan yang diduga oleh mereka sebagai kebenaran.

Para penghayal (filosof) itu, kata Ibnu Taimiyah, telah melewati jalan di sana dengan cara yang simpang siur. Mereka sering melontarkan kata-kata yang tidak terbatas maknanya dan ketentuan-ketentuan yang diklaimnya penting, padahal mereka sebenarnya memalsukan kebenaran. Sampai-sampai orang menyangka kebatilan mereka sebagai petunjuk. ${ }^{4}$

Serangan Ibnu Taimiyah dilanjutkan kemudian oleh tokoh-tokoh aliran Salaf lainnya seperti Ibnu 1-Qayyim, Muhammad bin Abdu al-Wahhab dan sebagainya.

Selain pandangan ulama yang menolak pemikiran filsafat, juga banyak lainnya yang menganggap sangat penting adanya filsafat itu, terutama sangat membantu dalam menjelaskan isi kandungan al-Qur'an dengan keterangan-keterangan yang dapat diterima oleh akal manusia. Al-Gazali sendiri walaupun secara eksplisit mengeritik para filosof, namun banyak juga menggunakan uraian-uraian filosofis dalam karya-karyanya termasuk dalam bidang tasawufnya.

Terlepas dari semua pandangan tersebut di atas para filosof Islam telah membentuk kubu tersendiri dalam mempertahankan eksistensi mereka. Mereka telah bertekad bulat dan menyatakan bahwa filsafat sama sekali tidak bertentangan dengan agama. Sedemikian jauhnya itu, seakan-akan mereka meyakini bahwa antara filsafat dan

\footnotetext{
${ }^{4}$ Bandingkan dengan keterangan Muhammad al-Bahiy, al-Fikru fi Tathawwurihi, diterjemahkan oleh Bambang Saiful Ma'arif dengan judul "Pemikiran Islam" (cetakan II, Bandung: Risalah, 1985), h., 116 .
} 
agama adalah dua saudara kembar yang harus dipertemukan dalam segala halnya.

Al-Kindi, sebagai filosof Islam yang pertama, menyatakan bahwa antara filsafat dan agama, keduanya adalah kebenaran. Selanjutnya al-Farabi menambahkan bahwa kebenaran yang dibawa oleh wahyu dan dihasilkan oleh filsafat hakekatnya hanya satu, sungguhpun bentuknya berbeda. Pendapat al-Farabi kemudian diteruskan oleh Ibnu Maskawaih dan Ibnu Sina, hal ini lebih jelas ketika membaca teori kenabian mereka.

Ibnu Tufail dalam karyanya "Hayy Ibn Yakzan" mempertunjukkan keharmonisan antara filsafat dan agama. Ia mengangkat sebuah kisah petualangan antara Hayy yang pada mulanya diasuh oleh seekor rusa yang kematian anak, lalu menemukan hakekat lewat akalnya setelah is dewasa; dan Absal, sebagai tokoh yang dibesarkan oleh agama Wahyu; keduanya bertemu di sebuah pulau terpencil, tempat Hayy dibesarkan. Lalu berdialoglah keduanya berdasarkan pengetahuan masing-masing, dan ternyata keduanya menemukan titik persamaan yaitu kebenaran yang hakiki. ${ }^{5}$

Ibnu Rusyd sebagai pembela filosof kelas wahid, meninjaunya dari segi lain. Ia bertolak dari pendapat umum, mengenai bolehnya menakwilkan ayat-ayat mutasyabih. Ibnu Rusyd menuturkan bahwa kalau ulama fiqhi dan kalam boleh menakwilkan ayatayat itu, maka tidak ada salahnya bagi filosof untuk melakukannya, bahkan filosof lebih berhak untuk itu karena merekalah yang lebih banyak menekuni bidang pemikiran. Dengan demikian filsafat mempunyai tempat yang sangat mulia dalam Islam. ${ }^{6}$

Dari uraian-uraian tersebut di atas, penulis tidak bermaksud mendukung pandangan yang anti kepada filsafat atau meyakini sepenuhnya pendirian filosof, yang penting bahwa kedua pernyataan itu perlu dipertimbangkan untuk menciptakan filsafat Islam yang lebih matang. Bagi penulis, tanpa mengurangi penghargaan kita pads filosof-filosof klasik Islam, ada baiknya mempertimbangkan penilaian dan kritikan tersebut sebab mungkin sekali terjadi bahwa hakekat filsafat Islam terletak di antara dua ujung yang berlawanan itu, mengingat bahwa filsafat Islam bukanlah suatu cara berpikir yang konstan, melainkan ia berkembang sesuai dengan perkembangan zaman, sebagaimana halnya proses yang dialami oleh filsafat sebelumnya.

\footnotetext{
${ }^{5}$ Bandingken dengan keterangan Harun Nasution, Akal dan Wahyu dalam Islam (cetakan II, Jakarta: UI Press, 1983), h. 82 dst.

${ }^{6}$ Lihat uraian selengkapnya Muhammad Yusuf Musa, Bain@ d-Din wa 1-Falsafah (cetakan II, Qairo: Darul Ma'arif, t.th), h. 91 dst.
} 
Filosof-filosof Islam klasik telah berhasil membuka cakrawala berpikir di kalangan umat pada masanya dengan jalan memperkenalkan cara berpikir bangsabangsa yang telah maju ketika itu, khususnya cara berpikir orang-orang Yunani. Kini tugas pemikir-pemikir muslim lebih berat lagi, yaitu bagaimana menyelamatkan agama di tengah-tengah perkembangan sains dan teknologi yang serba materialistik atau mengendalikan kebudayaan itu dari geraknya yang kehilangan arah dan tujuan hakiki.

\section{DAFTAR PUSTAKA}

Abduh, Syekh Muhammad. Risalatu t-Tauhid Qairo: Maktabah wa muthba'ah Muhammad Ali Shabih wa Auladih, 1965.

Al-Bahiy, Muhamaad, Dr. Al-Fikru 1-Islamiy fi Tatawwurih. Diterjemahkan oleh Bambang Saiful Ma'arif dengan judul "Pemikiran Islam." Cetakan I. Bandung: Risalah, 1985.

AI-Janibu i-ilahi mina t- Tafkir-i I- Islami. Jilid I \& II. Cetakan IV. Qairo : Daru I-Katibi I- Arabiy, 1976.

An- Nasysyar, Ali Samiy. Manahiju I-Bahts 'Inda Mufakkiri I-Islam. Cetakan I. Qairo: Daru I-Fikru I- Arabiy, 1967.

Gibb, Hamilton A.R. Dr. Hadza Huwa I- Islam. Diterjemahkan oleh Abu Salamah dengan judul “ Islam dalam Lintasan Sejarah.” Cetakan IV. Jakarta: Darata Karya Aksara, 1983.

Hanafi, Ahmad, Dr. Pengantar Filsafat Islam. Jakarta: Bulan Bintang, 1982. Theolo i Islam. Cetakan II. Jakarta: Bulan Bintang, 1977.

Musa, Muhammad Yusuf, Dr. Baina d-Din wa I- Filsafah. Cetakan II. Qairo: Daru IMa'arif, 1968.

Nasution, Harun, Dr. Akal dan wahyu dalam islam. Cetakan II, Jakarta : UI - Press. 